\title{
Article \\ Carbon Pricing and Complementary Policies-Consistency of
the Policy Mix for Decarbonizing Buildings in Germany
}

Sibylle Braungardt *, Veit Bürger and Benjamin Köhler (D)

Oeko-Institut, Merzhauser Str. 173, 79100 Freiburg, Germany; v.buerger@oeko.de (V.B.); b.koehler@oeko.de (B.K.)

* Correspondence: s.braungardt1@oeko.com

check for

updates

Citation: Braungardt, S.; Bürger, V.;

Köhler, B. Carbon Pricing and

Complementary Policies-

Consistency of the Policy Mix for

Decarbonizing Buildings in Germany.

Energies 2021, 14, 7143. https://

doi.org/10.3390/en14217143

Academic Editors: Dimitrios

Katsaprakakis, Vincenzo Bianco,

Olivier Bahn and Luigi Aldieri

Received: 3 September 2021

Accepted: 28 October 2021

Published: 1 November 2021

Publisher's Note: MDPI stays neutral with regard to jurisdictional claims in published maps and institutional affiliations.

Copyright: (C) 2021 by the authors Licensee MDPI, Basel, Switzerland. This article is an open access article distributed under the terms and conditions of the Creative Commons Attribution (CC BY) license (https:/ / creativecommons.org/licenses/by/ $4.0 /)$.

\begin{abstract}
While it is widely acknowledged that carbon pricing plays an important role in driving the transition towards a low-carbon energy system, its interaction with complementary instruments is discussed controversially. The analysis of combining carbon pricing with complementary policies has been mostly focused on the electricity sector, while the role of carbon pricing in the buildings sector has received only minor interest. In view of the newly introduced carbon pricing scheme for the buildings and transport sector in Germany, we analyze the interactions between the carbon pricing scheme with the existing policy instruments and assess the consistency of the policy mix for decarbonizing the buildings sector. Our analysis finds that the introduction of carbon pricing has a reinforcing effect on the instrument mix and adds to the consistency of the policy mix. The results highlight the importance of complementary policies in order to achieve deep decarbonization in the buildings sector. We conclude that carbon pricing, preferably implemented as a tax with a predictable and increasing price level, needs to be supplemented with a powerful mix of complementary measures.
\end{abstract}

Keywords: carbon pricing; policy mix; energy transition; buildings; climate policy

\section{Introduction}

Carbon pricing is considered an important element of climate policy and various schemes have been implemented by numerous countries and regions. According to the World Bank Carbon Pricing Dashboard [1], as of September 2021 a total of 64 carbon pricing schemes have been implemented globally, including 35 carbon taxes and 29 emissions trading schemes. The buildings sector is frequently covered in carbon taxing schemes, whereas only 11 emissions trading schemes cover the emissions of this sector (Beijing ETS, California CaT, Germany ETS, Korea ETS, Quebec Cat, Saitama ETS, Shanghai pilot ETS, Shenzhen pilot ETS, Tianjin pilot ETS, Tokyo CaT, Washington CAR). The prices implemented in the schemes covering the buildings sector range from $0.29 \mathrm{EUR} / \mathrm{t} \mathrm{CO} \mathrm{C}_{2} \mathrm{e}$ to $109 \mathrm{EUR} / \mathrm{t} \mathrm{CO} 2 \mathrm{e}$ for carbon taxes and $3 \mathrm{EUR} / \mathrm{t} \mathrm{CO}_{2} \mathrm{e}$ to $15 \mathrm{EUR} / \mathrm{t} \mathrm{CO} 2 \mathrm{e}$ for emissions trading schemes covering the buildings sector. The range reflects the variety of prices in the different schemes.

While the role of carbon pricing as an element of climate policy is widely acknowledged, the need for complementary policy instruments is discussed controversially. On the one hand, a large body of literature argues that carbon pricing provides the most efficient means for decarbonization, with complementary measures playing a minor role mainly to correct market failures [2-7]. On the other hand, an increasing body of literature highlights the fundamental role of complementary policies to achieve ambitious climate targets [7-15].

While the interaction of carbon pricing with complementary policies has been studied in the context of the energy transition in the power sector and industry $[6,12,16-18]$, the introduction of carbon pricing to support the transition of the buildings sector has received only marginal interest. With the building sector being responsible for $28 \%$ of global energyrelated $\mathrm{CO}_{2}$ emissions in 2019 [19], its decarbonization is essential for meeting goals of the Paris Agreement as well as national and regional climate targets. 
The buildings sector differs in various ways from other sectors, such that the assessment of the interactions between carbon pricing and complementary policies needs to reflect its specific characteristics. Firstly, $\mathrm{CO}_{2}$-emissions from the buildings sector are spread over a large amount of individual buildings, where a heterogeneous set of building owners decide upon the installed heating systems and the energy efficiency of the building envelope and where low price sensitivities prevail [20-24]. Secondly, the buildings sector faces the challenge of "split incentives", i.e., the distribution of costs and benefits between landlords and tenants [25-27]. Thirdly, the buildings sector is characterized by long lifespans of buildings components and low annual investment rates. Lastly, $\mathrm{CO}_{2}$-emissions from the buildings sector show large interannual variations due to temperature differences (warm vs. cold winters), presenting a potential challenge for implementing annual caps in emissions trading schemes.

The goal of this article is to assess the role of carbon pricing and its interaction with complementary policies for the decarbonization of buildings. Focusing on the example of the newly introduced carbon pricing scheme in Germany, we analyze the interactions of carbon pricing with the existing complementary policy instruments and assess the consistency and comprehensiveness of the resulting policy mix. The German Fuel Emissions Trading Act (Bundesemissionshandelsgesetz, BEHG) was adopted in 2019 and sets a price on greenhouse gas (GHG) emissions from the buildings and transport sectors since January 2021 with the aim of supporting the sectors in meeting the national climate targets. As the decarbonization of the buildings sector in Germany is covered by a variety of policy instruments aside from the newly introduced carbon pricing scheme, it is essential to assess the consistency of the resulting policy mix.

Our analysis uses the framework for analyzing policy mixes for sustainability transitions developed by Rogge and Reichardt [28]. The framework provides an extended conceptualization of policy mixes and has been used successfully for the analysis of policy mixes in other areas of environmental policy such as energy efficiency [29], renewable energies [28] and the bioeconomy [30,31].

The article is structured as follows. Section 2 describes the methodological approach used in the study. Section 3 presents the results of the analysis regarding the elements of the policy mix, the interaction between its policy instruments and its consistency. The conclusions and policy recommendations derived from our analysis are presented in Section 4.

\section{Materials and Methods}

A variety of methodological approaches to analyze policy mixes has been developed and applied across different fields of research in the area of energy and climate policy [32-35], where an increasing focus is given to extending the scope of the analysis beyond the mere interaction between policy instruments $[28,36]$.

In order to analyze the consistency of the policy mix for addressing the decarbonization of the buildings sector in Germany with the newly introduced carbon pricing scheme, we draw upon the framework for assessing policy mixes developed in [28]. According to the framework, the policy mix is defined as a combination of three building blocks: (1) elements, (2) processes and (3) characteristics [28]. The following subsections briefly describe these building blocks and define the scope and boundaries of our analysis.

\section{Elements of the policy mix}

The policy mix consists of three main elements:

1. The policy strategy is defined as a combination of policy objectives and the principal plans for achieving them. This work sets the scope as the national objectives and approach for addressing the decarbonization of the buildings sector. While the national strategy is influenced by the EU-level targets and strategies, the interaction between these two levels is not in the focus of our work.

2. Instruments are defined as concrete tools to achieve overarching objectives. Rogge (2016) propose a type-purpose classification of instruments including three types of 
instruments (economic instruments, regulations and information) and three primary purposes (technology push, demand pull, systemic). This work focuses on the existing national policies addressing the decarbonization of buildings, and policies at EU partially considered when showing a direct impact at national level.

3. The instrument mix combines the individual instruments and takes into account interactions between the instruments. In the analysis of interactions, we focus on the interaction between the newly introduced carbon pricing scheme with the remaining elements of the instrument mix.

\section{Processes}

The framework by [28] highlight the importance of considering policy processes, as the elements and characteristics of the policy mix are shaped by the underlying processes. In the context of the policy mix for decarbonizing the buildings sector in Germany, we include the analysis of the policy processes leading to the introduction of the carbon pricing scheme as well as the relevant policy developments at the EU level.

\section{Characteristics}

Key characteristics of the policy mix are the consistency of elements, the coherence of processes, together with the credibility and comprehensiveness of a policy mix [28]. While the coherence of processes, the credibility and comprehensives of the policy mix partly feeds into the analysis, our assessment focuses on the consistency of the policy mix.

To investigate the consistency of the policy mix, the authors of [28] suggest assessment of the following levels:

1. The consistency of the policy strategy is addressed by assessing the alignment of policy objectives and the consistency of principal action plans with the policy objectives.

2. The consistency of the instrument mix is addressed through interaction analysis, where instruments in an instrument mix are consistent when they reinforce rather than undermine each other in the pursuit of policy objectives.

3. The consistency of the instrument mix with the policy strategy addresses the interplay of the policy mix with the policy strategy, i.e., if the instrument mix is consistent with the policy objectives.

\section{Results and Discussion}

This section presents the results of our analysis, encompassing the analysis of the elements of the policy mix for decarbonizing buildings in Germany (Section 3.1), the policy processes (Section 3.2) and the assessment of the consistency of the policy mix (Section 3.3).

\subsection{Elements of the Policy Mix}

\subsubsection{Strategy}

The strategy for decarbonizing the buildings sector comprises the sectoral target for reducing GHG emissions in the buildings sector enshrined in the Federal Climate Protection law as well as the overarching approach to achieve the reduction objective.

A quantitative GHG-reduction target for the buildings sector in Germany for the year 2030 was first specified in 2016 in the Climate Action Plan 2050 [37] and was transposed into national law in the Federal Climate Change Act in 2019. The latter was revised in 2021 following an order of the Federal Constitutional Court concluding that the Federal Climate Change Act of 2019 is incompatible with fundamental rights insofar as it lacks sufficient specifications for further emission reductions from 2031 onward. The constitutional complaints were filed by young climate activists, supported by several environmental NGOs. The revised Federal Climate Change Act comprises the legislative framework for Germany's GHG reduction goal for 2030 and specifies the commitment to pursue greenhouse gas neutrality by 2045 as a long-term objective. By 2030, the Climate Change Act sets a reduction target of at least $65 \%$ with respect to 1990 levels (the target was increased from $-55 \%$ to $-65 \%$ in the revision in 2021). The Climate Change Act further specifies annual 
sectoral emission budgets for the following sectors: energy, industry, transport, buildings and agriculture. The annual emission budgets for the buildings sector are shown in Table 1.

Table 1. Annual emission budgets for the buildings sector specified in the German Climate Change Act.

\begin{tabular}{ccccccccccc}
\hline $\mathbf{2 0 2 0}$ & $\mathbf{2 0 2 1}$ & $\mathbf{2 0 2 2}$ & $\mathbf{2 0 2 3}$ & $\mathbf{2 0 2 4}$ & $\mathbf{2 0 2 5}$ & $\mathbf{2 0 2 6}$ & $\mathbf{2 0 2 7}$ & $\mathbf{2 0 2 8}$ & $\mathbf{2 0 2 9}$ & $\mathbf{2 0 3 0}$ \\
\hline \multicolumn{8}{c}{ Annual } & emission & budgets & for the \\
118 & 113 & 108 & 103 & 97 & 92 & 87 & 82 & 77 & 72 & 67 \\
\hline
\end{tabular}

Figure 1 compares the annual GHG budgets for the buildings sector (see Table 1) to the GHG emissions of the sector in the past 10 years and shows that considerable additional efforts are needed to meet the targets. Progress on achieving the sectoral targets is monitored and assessed annually and a readjustment mechanism is defined for sectors that deviate from the specified reduction trajectories. The responsibility for ensuring compliance with the annual emission budgets lies with the federal ministry whose remit covers the respective sector. The approach of setting sectoral emission budgets thus also fulfils a governance function. In 2020, with emissions of $120 \mathrm{Mt} \mathrm{CO}_{2} \mathrm{e}$, the buildings sector is the only sector exceeding its annual emissions budget laid down by the Climate Change Act.

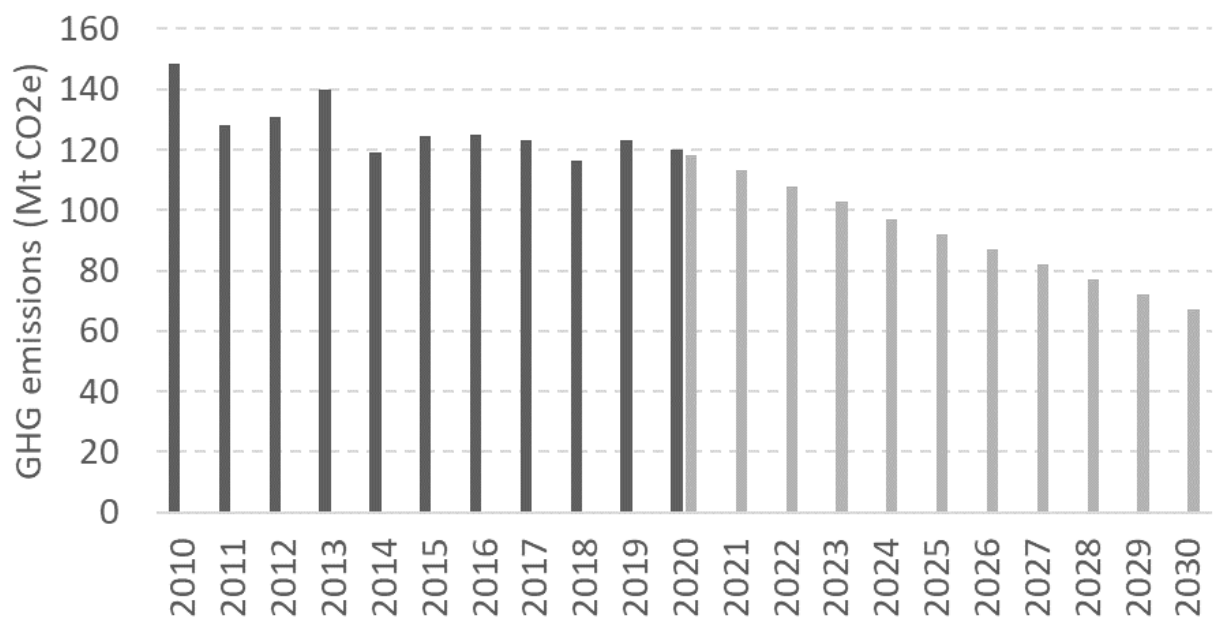

Figure 1. THG emissions of the buildings sector in Germany from 2010 to 2018, and emissions budgets for 2020-2030 according to the Federal Climate Change Act. Data available at https:// www.umweltbundesamt.de/daten/klima/treibhausgasminderungsziele-deutschlands (accessed on 29 September 2021).

The German government published its strategy for the decarbonization of the buildings sector in 2015 in the "Energy Efficiency Strategy for Buildings" [38], outlining the goal of achieving a "virtually climate neutral buildings stock" by 2050 through a combination of energy savings and the use of renewable energies. For a virtually climate-neutral building stock, the nonrenewable primary energy demand must decrease by at least $80 \%$ with respect to 2008 levels. The strategy proposes energy efficiency and renewable energies as key strategies and provides scenario calculations setting a corridor of reduction pathways.

\subsubsection{Instruments}

This section provides an overview of the policy instruments implemented in Germany to address the decarbonization of the buildings sector. As the focus of the analysis is the interaction between the existing instruments and the newly introduced carbon pricing scheme, we first provide a detailed description of the carbon pricing scheme, followed by a discussion on the remaining instruments. 


\section{Carbon pricing}

The German Fuel Emissions Trading Act (BEHG) passed in 2019 introduces a national emissions trading system for sectors that are not covered by the European emissions trading system (EU ETS). For the heating sector, the system covers the emissions from space and water heating in buildings along with emissions from heat produced in industrial processes insofar as these are not covered in the EU ETS. The obligated parties that are required to purchase and surrender allowances are the companies that place the fuels on the market.

The German carbon trading scheme can be considered a hybrid system including elements of a carbon tax as well as emissions trading. In an introductory phase covering the years 2021-2025, allowances are issued at a fixed price that increases on a yearly basis. In 2026, a price corridor including a price floor and price ceiling is defined. Starting from 2027, the Act foresees the specification of annually decreasing emission levels (caps), which contribute to meeting the sector targets under the Federal Climate Protection Act and to the reduction obligation under the EU Climate Protection Regulation.

During the introductory phase with a fixed-price system, emission allocations are sold to the obliged parties starting with a price of $25 \mathrm{EUR} / \mathrm{t} \mathrm{CO} \mathrm{CO}_{2} \mathrm{e}$ in 2021 and increasing to $55 \mathrm{EUR} / \mathrm{t} \mathrm{CO}_{2} \mathrm{e}$ by 2025 . For 2026, a price corridor is set with a minimum price of $55 \mathrm{EUR} / \mathrm{t} \mathrm{CO} \mathrm{CO}_{2} \mathrm{e}$ and a maximum price of $65 \mathrm{EUR} / \mathrm{t} \mathrm{CO}_{2} \mathrm{e}$. These prices were set in the Federal Government's declaration on record to the Bundesrat in December 2019 and were implemented in the first law amending the Fuel Emissions Trading Act, passed by the Federal Government in May 2020 [39].

The revenue of the carbon pricing scheme is partly used for measures to reduce the burden for consumers and industry, including a reduction of the surcharge on the electricity price under the Renewable Energy Sources Act, an increase of the commuting allowance for long-distance commuters and an increase of the housing cost supplement for low-income households.

\section{Complementary instruments}

In Germany, a variety of policy instruments to support the transition of the buildings sector are currently in place. Table 2 categorizes the existing instruments (excl. the newly introduced carbon pricing scheme) with respect to the typology introduced by [28]. A detailed description of the policy instruments is found in the German National Energy and Climate Plan (NECP) [39] and the Long-Term Renovation Strategy (LTRS) [40].

\section{Interactions with economic instruments}

Among the economic instruments implemented in Germany (see Table 2), the funding schemes for energy efficiency and renewable energies for heating and for district heating systems are the most prominent measures supporting the transition of space heating.

There are several reinforcing interactions between the funding schemes and the newly introduced carbon pricing scheme:

1. With the carbon pricing scheme increasing the economic benefits of renewable heating solutions and energy efficiency measures, it is likely that the uptake of the funding schemes increases with the introduction of carbon pricing.

2. Part of the revenues from the carbon pricing scheme are used to limit the electricity price for consumers by limiting the renewable energy surcharge. The reduced electricity price in combination with the higher fossil fuel prices provide an additional incentive to invest in heat pumps. This is particularly significant because heat pumps are seen as a key technology for decarbonizing the buildings sector.

The carbon pricing scheme foresees using parts of the revenues for funding further climate protection measures. Revenue recycling for climate protection measures can contribute significantly to increasing the impact of carbon pricing for reducing emissions [41,42], although introducing a possible tradeoff with regard to public acceptance of the schemes. For example, the Ontario cap-and-trade policy for GHG emissions was repealed due to acceptance issues, where the use of carbon revenue to fund climate change programs played a key role [43]. 
With increasing carbon prices, investments in energy efficient buildings and renewable heating become economically viable also without funding. In order to ensure an efficient instrument mix, funding for these technologies may gradually be reduced. This is particularly true for heat pumps, which benefit from the reduced electricity tariffs.

Table 2. Policies addressing the transition of the buildings sector in Germany.

\begin{tabular}{ll}
\hline Technology Push & Demand Pull \\
\hline Economic instruments & \\
& $\begin{array}{l}\text { Federal Support for Efficient Buildings (BEG: } \\
\text { energy-related renovations and high-efficiency } \\
\text { new-builds of residential and nonresidential }\end{array}$ \\
$\begin{array}{l}\text { Funding of serial } \\
\text { renovation work }\end{array}$ & $\begin{array}{l}\text { buildings, as well as individual renovation measures } \\
\text { Further development of } \\
\text { the innovative Future }\end{array}$ \\
$\begin{array}{l}\text { Building (Zukunft } \\
\text { Bau) program }\end{array}$ & $\begin{array}{l}\text { installations which use renewable energies to } \\
\text { geneat storage facilities and local heat networks, both }\end{array}$ \\
Building the & in residential and nonresidential buildings) \\
Energy Transition & Tax incentives for energy-related \\
(Energiewendebauen) ini- & building renovations \\
tiative & Funding for mini cogeneration plants \\
\end{tabular}

\section{Regulation}

Buildings Energy Act (Building Code): Minimum energy efficiency standards for new buildings and major renovations; renewable energy quota for new buildings; restrictions on the installation of oil-fired boilers from 2026.

EU level: Minimum standards and labels for heating and cooling appliances under the

Ecodesign Directive

\section{Information}

Independent consultancy services provided by National Consumer Agency (Verbraucherzentrale Bundesverband e.V., vzbv)

Federal funding for energy consulting for residential buildings (on-site consulting, individual renovation roadmap)

Energy consulting for nonresidential buildings owned by municipalities/charitable organizations Federal funding for energy consulting for SMEs National efficiency label for old heating installations

\section{Systemic}

Heating Network Systems 4.0: Expansion of funding program for heating networks, heat storage systems and multibuilding investments Energy-efficient urban redevelopment and further development of the Urban Development Funding Program Funding of energy performance contract consulting within the framework of energy consulting for nonresidential buildings owned by municipalities/charitable organizations Model energy saving contracting projects Municipality-level energy efficiency and resource efficiency networks

Exemplary role of federal buildings Submetering (planned implementation: additional billing information during the year)

Dialogue on contracting between the Federal

Government and the federal states Information on sample contracts and guidelines (contracting) Information and Competency Center for Future-Oriented Construction

Source: German National Energy and Climate Plan and Long Term Renovation Strategy.

\section{Interactions between carbon pricing and regulations}

The German Buildings Energy Act sets the key regulatory framework for buildings in Germany including minimum energy efficiency requirements for new buildings and major renovations, RES-quota for new buildings and limits the installation of oil-fired heating systems from 2026. Regarding the minimum requirements for energy efficiency, the newly introduced carbon pricing scheme introduces a reinforcing interaction-when setting the ambition level of the minimum requirements, the regulation is based on the principle of economic efficiency (see Buildings Energy Act $§ 1$ (2)), meaning that requirements need to be economically profitable from the perspective of the building owner. In absence of carbon pricing to internalize the external costs, the approach of basing minimum requirement on the principle of economic efficiency inevitably leads to minimum requirements that are not consistent with the policy targets for reducing GHG emissions. 
With the introduction of the carbon pricing scheme, the economic assessment to support the specification of the minimum requirements shifts towards more ambitious requirements. However, while the prices introduced in the carbon pricing scheme do not reflect the full external costs, the approach of basing minimum requirements on the principle of economic efficiency from the perspective of building owners continues to lead to low ambition levels that are not consistent with the decarbonization targets.

Considering the dimension of time in the interaction between minimum requirements in the Buildings Energy Act and carbon pricing, the review of the energy requirements is not aligned to the introduction of the carbon pricing scheme. While the carbon pricing is in place since January 2021, the review of the energy requirements was originally scheduled for the year 2023, such that the ambition level of the requirements is not adjusted until three years later. In the context of the revision of the Federal Climate Change Act, the government adopted an immediate climate action program, which, among others, brings forward the revision of the Buildings Energy Act to the year 2022 [44].

Regarding the regulation on submetering specified in the Heating Cost Ordinance (Heizkostenverordnung), the interaction with the carbon pricing scheme depends on the regulatory approach for distributing the costs of carbon pricing between buildings owners and tenants. While the costs are currently fully passed on to the tenants, the Climate Action Program 2030 [45] states that options for regulatory changes distributing the costs between landlords and tenants are assessed. In May 2021, in the context of the revision of the Federal Climate Change Act, a cabinet decision proposed an equal distribution of the costs between landlords and tenants; however, in June 2021 no agreement could be achieved (https:/ / www.tagesschau.de/inland/mieter-co2-preis-101.html, accessed on 29 September 2021). The costs of carbon pricing therefore continue to be fully borne by the tenants.

\section{Interaction with information}

For all existing instruments providing information to consumers and stakeholders in the heat market (Table 2), the interaction with carbon pricing is reinforcing. With increased prices for fossil-based heating systems, the need for guidance on energy saving measures together with the use of renewable energies increases and it is more likely that the proposed measures are implemented.

\subsection{Policy Process}

Following the methodology for analyzing policy mixes proposed by [28], this section discusses the policy process associated with the introduction of the German carbon pricing scheme and the simultaneously ongoing processes at EU level related to carbon pricing. Figure 2 provides an overview of key milestones of the respective processes in Germany and the EU.

The German carbon pricing scheme was introduced as part of the Climate Protection Program 2030 published in September 2019 [45], a comprehensive policy package aimed at supporting the achievement of the German climate protection targets for 2030. The communication outlines the characteristics of the carbon pricing scheme, including its introduction as an emissions trading system with a fixed-price phase until 2025 and the foreseen price levels. The adoption of the Fuel Emissions Trading Act followed in November 2019 with a price path from $10 \mathrm{EUR} / \mathrm{t}$ in 2021 to $35 \mathrm{EUR} / \mathrm{t}$ in 2025, which was increased to a path of $25 \mathrm{EUR} / \mathrm{t}$ in 2021 to $55 \mathrm{EUR} / \mathrm{t}$ in 2030 in October 2020.

The introduction of the German scheme for pricing carbon under the Fuel Emissions Trading Act followed a controversial discussion between the parties forming the German government in 2019. The discussion formed part of the activities of the "climate cabinet", a cabinet committee on climate protection set up by the Federal Government with the aim of developing a policy package to ensure compliance with the climate targets for 2030. 


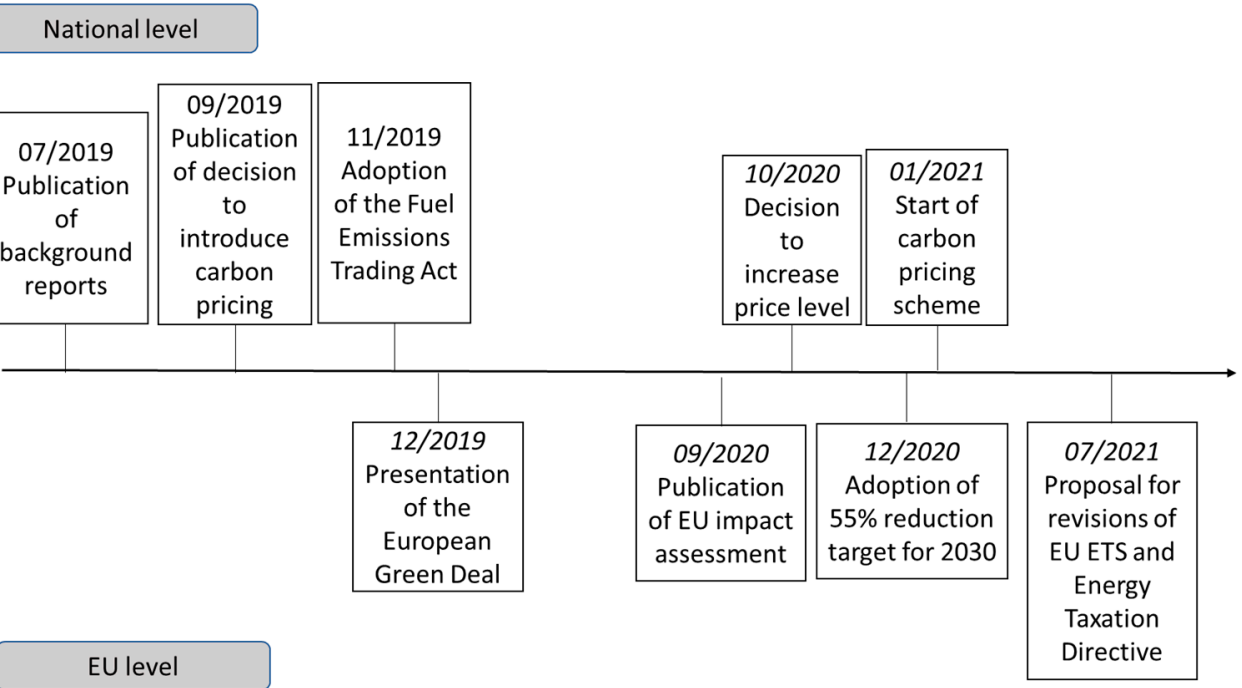

Figure 2. Overview of timeline of policy processes in the context of the introduction of carbon pricing in Germany.

Within the coalition between the CDU/CSU (Christian Democratic Union of Germany, CDU; Christian Social Union in Bavaria, CSU) and SPD (Social Democratic Party of Germany), the parties showed differing positions not only with respect to the price level but also with respect to the general approach for pricing carbon-whereas the SPD favored a carbon tax, the CDU/CSU strictly opposed this approach. Ahead of the decisions of the "climate cabinet" on a climate protection package in September 2019, the Federal Ministry for the Environment, Nature Conversation and Nuclear Safety lead by the SPD published several studies assessing the introduction of a national $\mathrm{CO}_{2}$-tax in June/July 2019 [46,47]. By contrast, the CDU-led Federal Minisitry for Economic Affairs and Energy draws upon an assessment of German Council of Economic Experts [48] and concludes that a national emissions trading system is the preferred option, partly to ensure a potential future integration in an EU-wide system [49].

The resulting hybrid approach introduced in the policy package published in September 2019 can be seen as a compromise between the two positions, with the fixed-price phase until 2025 sharing the characteristics of a $\mathrm{CO}_{2}$-tax.

At the EU level, in the context of the European Green Deal, the proposal for the revised Emissions Trading Directive presented in July 2021 foresees the introduction of a separate new emissions trading system for fuels for road transport and buildings [50]. The timing of the policy developments at national and EU level are shown in Figure 2.

\subsection{Consistency of the Policy Mix}

\subsubsection{Consistency of the Policy Strategy}

For the year 2030, the Climate Change Act provides a binding framework for emissions reductions at the national level, ensuring that the sectoral contributions for reducing GHG emissions are consistent with the national target. The target for the buildings sector is therefore consistent with the national objectives. The ambition of the national objectives was increased in June 2021 in the context of both the order of the Federal Court and the increase of the ambition of the climate target for 2030 at EU level [51].

The general approach for meeting the sectoral target for buildings is specified in the Energy Efficiency Strategy for Buildings [38]. However, the approach is not fully consistent with the objectives-the strategy contains the target of "virtual" climate neutrality for the buildings sector for 2050, being defined as a state in which the sector's nonrenewable primary energy demand decreases by at least $80 \%$ with respect to 2008 levels. This corresponds roughly to a reduction in GHG emissions of the same magnitude. This is not consistent with the (more ambitious) overall national target of GHG-neutrality for which a complete decarbonization of the sector is necessary. Furthermore, the strategy 
does not reflect the ample policy developments since 2015, including the adoption of the Climate Protection Plan 2050, the Climate Action Program 2030 and the Federal Climate Change Act. These new developments seem to be integrated and considered in the recent communications of the ministry, where the term "virtual" is no longer used and the target of a climate neutral buildings sector is used [52]. However, it is not yet integrated in official strategies.

\subsubsection{Consistency of the Instrument Mix}

Given the reinforcing interactions of carbon pricing with the remaining elements of the instrument mix (see Section 3.1.1), the introduction of carbon pricing provides a consistent extension of the instrument mix. Besides the positive effects on the uptake of funding schemes and information measures, the consistency of the instrument mix increases with the introduction of carbon pricing as the regulatory requirements are shifted towards ambition levels that are consistent with the objectives (see Section 3.1.1).

Based on the controversial discussion on the interaction of carbon pricing schemes with complementary instruments [2,3,8-12], this section reviews key arguments supporting the need for complementary instruments when introducing carbon pricing schemes and discusses them in the context of the German policy mix for buildings.

1. Time and ambition: Meeting ambitious climate targets requires fast and ambitious climate action. Not only "low-hanging fruits", but also more expensive technologies need to be diffused on a short timescale [8,10], particularly in view of the very long investment cycles in the building sector. Carbon pricing does typically not lead to deep emissions reductions, such that even in countries with high prices only incremental emissions reductions occur and complementary phase-out policies are introduced [53].

2. Political feasibility: Even though carbon pricing plays an increasing role in climate policy, the currently implemented schemes are at a price level that is not consistent with ambitious climate actions. Prices that would be needed in order to meet the agreed targets would be high and unlikely to be implemented $[8,53,54]$. For the German carbon pricing scheme to provide a relevant contribution to meeting the reduction targets for the buildings sector, carbon prices would need to be increased considerably as compared to the price path specified for the years 2021-2025. For example, the German National Energy and Climate Plan submitted to the EU Commission in 2020 assumes that carbon pricing increases the consumer prices of national gas by $62 \%$ and oil by $47 \%$ to support the calculations for target achievement, reflecting prices that are far above the current price levels. It does not seem likely that price increases of the required magnitude will be politically feasible.

3. Market failures and imperfections: Complementary instruments are needed in order to correct market failures and imperfections, such as information asymmetries and split incentives [7]. Market failures and imperfections play a crucial role for the decarbonization of the buildings sector. The buildings sector is characterized by a large number of structural and nonmonetary barriers, including the lack of knowledge and interest of building owners, the distribution of costs and benefits between landlords and tenants as well as decision-making based on heuristic approaches rather than rational behavior [55-58]. In Germany, the structure of the housing sector with more than half of the households living in rented dwellings poses a considerable challenge. As the costs for carbon emissions are currently borne entirely by the tenants, the carbon pricing scheme does not provide direct incentives for the owners of rented buildings to invest in energy efficiency measures and renewable heating [59].

4. Carbon pricing does not foster innovation in new technologies, such that complementary policies are needed to support innovation $[8,12,60]$. The full decarbonization of the buildings sector requires innovation in technologies and processes for thermal retrofit and renewable heating systems. An important example are innovative industrial supply chain approaches to thermal retrofit, which are expected to decrease 
the cost, time and on-site labor intensity of deep thermal retrofits. The decrease of on-site labor is of particular importance for the transformation of the buildings stock in Germany, as key climate protection scenarios show that the annual refurbishment rate needs to more than double to meet the targets (e.g., [61-63], while already at current levels Germany faces a shortage of skilled workers [64].

In view of the hybrid approach of the carbon pricing scheme in Germany, combining a fixed-price phase with a cap-and-trade approach (see Section 3.1.2), several authors have expressed concerns whether the hybrid nature of the approach is consistent with German constitutional law $[65,66]$.

Despite of the potential legal issues related to the instrument, we analyze the consistency of the instrument mix considering the two approaches. In this context, [5] analyze the combination of complementary policies with carbon pricing and find that a combination with a carbon tax is more effective than with a cap-and-trade scheme, as in the former carbon prices are not impacted by the complementary policies. Furthermore, carbon taxes with a fixed and rising price path increase the predictability for investors and support long-term investment decisions in low-carbon technologies.

For the buildings sector, a cap-and-trade scheme faces the challenge that intrayearly fluctuations of the energy demand due to temperature changes are large (warm vs. cold winters), such that the availability and price of certificates depends on whether conditions. The magnitude of the effect of such fluctuations depends on the overall size of the emissions trading scheme-when the emissions from the buildings sector make up for a high share of the total emissions covered in the scheme, the effect on the availability and prices is higher.

For the case of the carbon pricing scheme in Germany, a recent estimate finds that the intrayearly fluctuations of $\mathrm{CO}_{2}$-emissions due to temperature differences may have an important impact on the availability and price level of certificates. While the fluctuations range up to $14 \mathrm{Mt} \mathrm{CO}_{2} \mathrm{e}$, with an estimated average of $6 \mathrm{Mt} \mathrm{CO}_{2} \mathrm{e}$, the $\mathrm{CO}_{2}$-emissions covered in the scheme need to be reduced by around $15 \mathrm{Mt} \mathrm{CO}_{2} \mathrm{e}$ per year between 2020 and 2030 [67].

\subsubsection{Consistency of the Policy Mix}

As discussed in the previous section, it is likely that the GHG emission reductions induced by the current instrument mix (including $\mathrm{CO}_{2}$ pricing) are insufficient to meet the sector target $[68,69]$, thus leading to an inconsistency of the instrument mix and the policy strategy.

The projections provided in the German NECP conclude that the objectives can be achieved with the instrument mix, however, with carbon prices that more than triple after the fixed price period ending in 2026. The corresponding sudden price jump does not seem politically feasible and would considerably affect the predictability and credibility of the scheme.

Unless the pricing levels are increased considerably before the end of the fixed-price phase in 2026, the impact of the carbon pricing scheme on achieving the 2030 target is limited due to the long investment cycles in the buildings sector. Given the long lifetimes of building components and heating systems, clear phase-out regulations going beyond the currently adopted limitations for the use of oil-boilers starting from 2026 are required. An additional element could be regulatory approaches in the form of specific refurbishment requirements, e.g., starting with the worst performing buildings.

At a structural level, the introduction of a carbon pricing scheme for the buildings and transport sectors with a common cap for both sectors is inconsistent with the approach of sectoral targets for these sectors as defined in the Climate Change Act. Unless the abatement costs are equal in both sectors, a common cap would lead to excessive fulfillment of the target in the sector with lower abatement costs, whereas the sector with higher abatement costs would not reach the target. However, the issue only arises if a fixed cap is set at the emissions levels following the Climate Change Act, which is unlikely as this would lead to prices that are beyond political feasibility. 


\section{Conclusions}

The analysis of the German policy mix for the decarbonization of the buildings sector shows that the newly introduced carbon pricing scheme interacts reinforcingly with the remaining policy instruments and adds to the consistency of the policy mix.

The results show that the deep and fast decarbonization of the buildings sector requires a mix of policy instruments, where aside from carbon pricing complementary instruments need to shape the transition pathways. In view of the variety of noneconomic barriers that persist in the buildings sector and the long lifetime of building components and heating systems, deep decarbonization cannot exclusively rely on carbon pricing but also requires regulatory measures to ensure that retrofit measures are consistent with the medium- and long-term targets and that fossil fuel technologies are phased out. Furthermore, innovation in technologies and processes that are required to meet the long-term targets need to be supported through complementary policies.

In order to maximize the impact of carbon pricing schemes in the buildings sector, it is essential that the price signal addresses all building owners including those of rented buildings, as the decision to invest in low-carbon technologies is typically taken by building owners. For the case of Germany, where carbon pricing is in place and the costs are currently borne exclusively by tenants, we recommend a fast implementation of the necessary regulatory changes to distribute the costs between landlords and tenants. For future carbon pricing schemes for the buildings sector in other jurisdictions we recommend that the respective regulatory framework is developed in advance of introducing the scheme.

Regarding the choice of the approach for carbon pricing, the analysis of the German scheme identifies the following challenges with introducing cap-and-trade schemes for the buildings sector. Firstly, unless an ambitious mix of complementary instruments ensures that the decarbonization of the sector is on track, the introduction of a cap which is consistent with the ambitious climate targets would lead to prices beyond political feasibility and which would lead to considerable negative social impacts. Secondly, the large intrayearly fluctuations of energy demand from the buildings sector depending on outside temperature have a significant impact on the amount of required emissions allowances. This effect is particularly pronounced in cap-and-trade systems with a small sectoral coverage, as it is the case in Germany. The effect needs to be taken into account when designing the schemes for borrowing and banking of allowances. Thirdly, a general issue with cap-and-trade systems covering the buildings sector is that the schemes are typically implemented as an upstream approach, where the obliged entities cannot directly conduct measures to reduce GHG emissions.

The analysis concludes that a consistent policy mix for the decarbonization of the buildings sector should include carbon pricing, preferably implemented as a tax with a predictable and increasing price level, but requires a powerful mix of complementary measures to steer the sector towards the deep decarbonization needed to achieve ambitious climate targets consistent with the targets of the Paris Agreement.

Author Contributions: Conceptualization, S.B.; methodology, S.B. and V.B.; formal analysis, S.B., V.B. and B.K.; writing—original draft, S.B.; writing—review and editing, V.B. and B.K. All authors have read and agreed to the published version of the manuscript.

Funding: This research received no external funding.

Institutional Review Board Statement: Not applicable.

Informed Consent Statement: Not applicable.

Conflicts of Interest: The authors declare no conflict of interest. 


\section{References}

1. World Bank. Carbon Pricing Dashboard. Up-to-Date Overview of Carbon Pricing Initiatives. Available online: https:// carbonpricingdashboard.worldbank.org/ (accessed on 6 October 2021).

2. Baranzini, A.; Van den Bergh, J.C.; Carattini, S.; Howarth, R.B.; Padilla, E.; Roca, J. Carbon pricing in climate policy: Seven reasons, complementary instruments, and political economy considerations. Wiley Interdiscip. Rev. Clim. Chang. 2017, 8, e462. [CrossRef]

3. High-Level Commission on Carbon Prices. Report of the High-Level Commission on Carbon Prices; World Bank: Washington, DC, USA, 2017.

4. Bergh, J.V.D.; Botzen, W. Low-carbon transition is improbable without carbon pricing. Proc. Natl. Acad. Sci. USA 2020, 117, 23219-23220. [CrossRef]

5. Bertram, C.; Luderer, G.; Pietzcker, R.; Schmid, E.; Kriegler, E.; Edenhofer, O. Complementing carbon prices with technology policies to keep climate targets within reach. Nat. Clim. Chang. 2015, 5, 235-239. [CrossRef]

6. Kalkuhl, M.; Edenhofer, O.; Lessmann, K. Renewable energy subsidies: Second-best policy or fatal aberration for mitigation? Resour. Energy Econ. 2013, 35, 217-234. [CrossRef]

7. Jaffe, A.B.; Newell, R.G.; Stavins, R.N. A tale of two market failures: Technology and environmental policy. Ecol. Econ. 2005, 54, 164-174. [CrossRef]

8. Mehling, M.; Tvinnereim, E. Carbon Pricing and the $1.5^{\circ} \mathrm{C}$ Target: Near-Term Decarbonisation and the Importance of an Instrument Mix. Carbon Clim. Law Rev. 2018, 12, 50-61. [CrossRef]

9. Klenert, D.; Mattauch, L.; Combet, E.; Edenhofer, O.; Hepburn, C.; Rafaty, R.; Stern, N. Making carbon pricing work for citizens. Nat. Clim. Chang. 2018, 8, 669-677. [CrossRef]

10. Patt, A.; Lilliestam, J. The Case against Carbon Prices. Joule 2018, 2, 2494-2498. [CrossRef]

11. Rosenbloom, D.; Markard, J.; Geels, F.W.; Fuenfschilling, L. Opinion: Why carbon pricing is not sufficient to mitigate climate change-And how "sustainability transition policy" can help. Proc. Natl. Acad. Sci. USA 2020, 117, 8664-8668. [CrossRef] [PubMed]

12. Del Río, P. Why does the combination of the European Union Emissions Trading Scheme and a renewable energy target makes economic sense? Renew. Sustain. Energy Rev. 2017, 74, 824-834. [CrossRef]

13. Matthes, F.C. Greenhouse Gas Emissions Trading and Complementary Policies: Developing a Smart Mix for Ambitious Climate Policies. 2010. Available online: https:/ /www.oeko.de/oekodoc/1068/2010-114-en.pdf (accessed on 29 September 2021).

14. Bataille, C.; Guivarch, C.; Hallegatte, S.; Rogelj, J.; Waisman, H. Carbon prices across countries. Nat. Clim. Chang. 2018, 8, 648-650. [CrossRef]

15. Twomey, P. Rationales for Additional Climate Policy Instruments under a Carbon Price. Econ. Labour Relat. Rev. 2012, 23, 7-31. [CrossRef]

16. Yin, G.; Zhou, L.; Duan, M.; He, W.; Zhang, P. Impacts of carbon pricing and renewable electricity subsidy on direct cost of electricity generation: A case study of China's provincial power sector. J. Clean. Prod. 2018, 205, 375-387. [CrossRef]

17. Shahnazari, M.; McHugh, A.; Maybee, B.; Whale, J. Overlapping carbon pricing and renewable support schemes under political uncertainty: Global lessons from an Australian case study. Appl. Energy 2017, 200, 237-248. [CrossRef]

18. Palmer, K.; Paul, A.; Woerman, M.; Steinberg, D.C. Federal policies for renewable electricity: Impacts and interactions. Energy Policy 2011, 39, 3975-3991. [CrossRef]

19. IEA. Tracking Buildings 2020. Available online: https://www.iea.org/reports/tracking-buildings-2020\# (accessed on 5 January 2021).

20. Asche, F.; Nilsen, O.B.; Tveterås, R. Natural Gas Demand in the European Household Sector. Energy J. 2008, 29, 27-46. [CrossRef]

21. Bissiri, M.; Reis, I.F.; Figueiredo, N.C.; da Silva, P.P. An econometric analysis of the drivers for residential heating consumption in the UK and Germany. J. Clean. Prod. 2019, 228, 557-569. [CrossRef]

22. Estrada, J.; Fugleberg, O. Price Elasticities of Natural Gas Demand in France and West Germany. Energy J. 1989, 10, 77-90. [CrossRef]

23. Filippini, M.; Kumar, N. Gas demand in the Swiss household sector. Appl. Econ. Lett. 2020, 28, 359-364. [CrossRef]

24. Labandeira, X.; Labeaga, J.M.; López-Otero, X. A meta-analysis on the price elasticity of energy demand. Energy Policy 2017, 102, 549-568. [CrossRef]

25. Charlier, D. Energy efficiency investments in the context of split incentives among French households. Energy Policy 2015, 87, 465-479. [CrossRef]

26. Kemp, P.A.; Kofner, S. Contrasting Varieties of Private Renting: England and Germany. Int. J. Hous. Policy 2010, 10, 379-398. [CrossRef]

27. Melvin, J. The split incentives energy efficiency problem: Evidence of underinvestment by landlords. Energy Policy 2018, 115, 342-352. [CrossRef]

28. Rogge, K.S.; Reichardt, K. Policy mixes for sustainability transitions: An extended concept and framework for analysis. Res. Policy 2016, 45, 1620-1635. [CrossRef]

29. Rosenow, J.; Kern, F.; Rogge, K.S. The need for comprehensive and well targeted instrument mixes to stimulate energy transitions: The case of energy efficiency policy. Energy Res. Soc. Sci. 2017, 33, 95-104. [CrossRef]

30. Purkus, A.; Hagemann, N.; Bedtke, N.; Gawel, E. Towards a sustainable innovation system for the German wood-based bioeconomy: Implications for policy design. J. Clean. Prod. 2018, 172, 3955-3968. [CrossRef] 
31. Imbert, E.; Ladu, L.; Morone, P.; Quitzow, R. Comparing policy strategies for a transition to a bioeconomy in Europe: The case of Italy and Germany. Energy Res. Soc. Sci. 2017, 33, 70-81. [CrossRef]

32. González, P.D.R. The interaction between emissions trading and renewable electricity support schemes. An overview of the literature. Mitig. Adapt. Strat. Glob. Chang. 2007, 12, 1363-1390. [CrossRef]

33. Kern, F.; Howlett, M. Implementing transition management as policy reforms: A case study of the Dutch energy sector. Policy Sci. 2009, 42, 391-408. [CrossRef]

34. Kern, F.; Kivimaa, P.; Martiskainen, M. Policy packaging or policy patching? The development of complex energy efficiency policy mixes. Energy Res. Soc. Sci. 2017, 23, 11-25. [CrossRef]

35. Nilsson, M.; Zamparutti, T.; Petersen, J.E.; Nykvist, B.; Rudberg, P.; McGuinn, J. Understanding Policy Coherence: Analytical Framework and Examples of Sector-Environment Policy Interactions in the EU. Environ. Policy Gov. 2012, 22, 395-423. [CrossRef]

36. Kern, F.; Rogge, K.S.; Howlett, M. Policy mixes for sustainability transitions: New approaches and insights through bridging innovation and policy studies. Res. Policy 2019, 48, 103832. [CrossRef]

37. BMUB. Climate Action Plan 2050-Principles and Goals of the German Government's Climate Policy. Federal Ministry for the Environment; Nature Conservation; Building and Nuclear Safety. 2016. Available online: https://www.bmu.de/fileadmin/ Daten_BMU/Pools/Broschueren/klimaschutzplan_2050_en_bf.pdf (accessed on 29 September 2021).

38. BMWI. Energy Efficiency Strategy for Buildings. Bundesministerium für Wirtschaft und Energie. 2015. Available online: https:// www.bmwi.de/Redaktion/EN/Artikel/Energy/energy-efficiency-strategy-for-buildings.html (accessed on 29 September 2021).

39. Bundesregierung. Integrated National Energy and Climate Plan. 2020. Available online: https:/ / ec.europa.eu/energy/sites/ default/files/documents/de_final_necp_main_en.pdf (accessed on 29 September 2021).

40. Bundesregierung. Long-Term Renovation Strategy of the Federal Government. 2020. Available online: https:/ / ec.europa.eu/ energy/sites/default/files/documents/de_2020_ltrs_official_en_translation.pdf (accessed on 29 September 2021).

41. Corradini, M.; Costantini, V.; Markandya, A.; Paglialunga, E.; Sforna, G. A dynamic assessment of instrument interaction and timing alternatives in the EU low-carbon policy mix design. Energy Policy 2020, 120, 73-84. [CrossRef]

42. Freyre, A.; Klinke, S.; Patel, M.K. Carbon tax and energy programs for buildings: Rivals or allies? Energy Policy 2020, $139,111218$. [CrossRef]

43. Raymond, L. Carbon pricing and economic populism: The case of Ontario. Clim. Policy 2020, 20, 1127-1140. [CrossRef]

44. BMF. Immediate Climate Action Programme for 2022. Available online: https://www.bundesfinanzministerium.de/Content/ EN/Standardartikel/Topics/Priority-Issues/Climate-Action/immediate-climate-action-programme-for-2022.html (accessed on 4 October 2021).

45. Bundesregierung. Eckpunkte für das Klimaschutzprogramm 2030. 2019. Available online: https://www.bundesfinanzministerium. de/Content/DE/Standardartikel/Themen/Schlaglichter/Klimaschutz/2019-09-20-Eckpunkte-Klimaschutz-Download.pdf? blob=publicationFile\&v=4 (accessed on 29 September 2021).

46. FÖS. Lenkungs- und Verteilungswirkungen einer klimaschutzorientierten Reform der Energiesteuern. 2019. Available online: https: / / foes.de/pdf/2019-07-FOES_CO2Preis_Hintergrundpapier_BMU.pdf (accessed on 29 September 2021).

47. DIW. Für eine Sozialverträgliche $\mathrm{CO}_{2}$-Bepreisung. 2019. Available online: https://www.diw.de/documents/publikationen/73 /diw_01.c.635193.de/diwkompakt_2019-138.pdf (accessed on 29 September 2021).

48. German Council of Economic Experts. Aufbruch zu einer neuen Klimapolitik. 2019. Available online: https://www sachverstaendigenrat-wirtschaft.de/fileadmin/dateiablage/gutachten/sg2019/sg_2019.pdf (accessed on 29 September 2021).

49. BMWI. Ein CO2-Preis-aber Wie? Available online: https://www.bmwi.de/Redaktion/DE/Schlaglichter-der-Wirtschaftspolitik/ 2019/08/kapitel-1-6-ein-co2-preis-aber-wie.html (accessed on 29 September 2021).

50. EU Commission. Proposal for a Directive of the European Parliament and of the Council Amending Directive 2003/87/EC Establishing a System for Greenhouse Gas Emission Allowance Trading within the Union, Decision (EU) 2015/1814 Concerning the Establishment and Operation of a Market Stability Reserve for the Union Greenhouse Gas Emission Trading Scheme and Regulation (EU) 2015/757. 2021. Available online: https:/ / eur-lex.europa.eu/legal-content/EN/TXT/?uri=CELEX\%3A52021 PC0551 (accessed on 29 September 2021).

51. EU Commission. Stepping up Europe's 2030 Climate Ambition: Investing in a Climate-Neutral Future for the Benefit of our People. $\operatorname{COM}(2020) 562$ Final. 2020. Available online: https://eur-lex.europa.eu/legal-content/EN/TXT/?uri=COM:2020:562:FIN (accessed on 29 September 2021).

52. BMWI. Dialog Klimaneutrale Wärme-Zielbild, Bausteine und Weichenstellungen 2030/2050. 2021. Available online: https: //www.bmwi.de/Redaktion/DE/Publikationen/Energie/dialog-klimaneutrale-waerme-zielbild-bausteine-weichenstellung2030-2050.pdf?_blob=publicationFile\&v=16 (accessed on 29 September 2021).

53. Tvinnereim, E.; Mehling, M. Carbon pricing and deep decarbonisation. Energy Policy 2018, 121, 185-189. [CrossRef]

54. Jenkins, J.D.; Karplus, V.J. Carbon Pricing under Binding Political Constraints; United Nations University World Institute for Development Economics Research: Helsinki, Finland, 2016; ISBN 978-92-9256-087-4.

55. Vogel, J.A.; Lundqvist, P.; Arias, J. Categorizing Barriers to Energy Efficiency in Buildings. Energy Procedia 2015, 75, 2839-2845. [CrossRef]

56. Phillips, Y. Landlords versus tenants: Information asymmetry and mismatched preferences for home energy efficiency. Energy Policy 2012, 45, 112-121. [CrossRef] 
57. Palm, J.; Reindl, K. Understanding barriers to energy-efficiency renovations of multifamily dwellings. Energy Effic. $2018,11,53-65$. [CrossRef]

58. Gigerenzer, G.; Gaissmaier, W. Heuristic Decision Making. Annu. Rev. Psychol. 2011, 62, 451-482. [CrossRef]

59. Oeko-Insitut; Klinski, S. Begrenzung der Umlagemöglichkeit der Kosten Eines Brennstoff-Emissionshandels auf Mieter*innen 2020. Available online: https://www.oeko.de/fileadmin/oekodoc/Kurzstudie-Umwaelzung-CO2-Bepreisung.pdf (accessed on 29 September 2021).

60. Sandén, B.A.; Azar, C. Near-term technology policies for long-term climate targets-economy wide versus technology specific approaches. Energy Policy 2005, 33, 1557-1576. [CrossRef]

61. Dena. Szenarien für Eine Marktwirtschaftliche Klima-und Ressourcenschutzpolitik 2050 im Gebäudesektor. Deutsche EnergieAgentur. 2017. Available online: https://www.dena.de/fileadmin/dena/Dokumente/Pdf/9220_Gebaeudestudie_Szenarien_ Klima-_und_Ressourcenschutzpolitik_2050.pdf (accessed on 29 September 2021).

62. Bürger, V.; Hesse, T.; Köhler, B.; Palzer, A.; Engelmann, P. German Energiewende-Different visions for a (nearly) climate neutral building sector in 2050. Energy Effic. 2019, 12, 73-87. [CrossRef]

63. Öko-Institut; Fraunhofer ISI. Klimaschutzszenario 2050-2. Endbericht. 2015. Available online: https://www.oeko.de/oekodoc/24 51/2015-608-de.pdf (accessed on 29 September 2021).

64. Kenkmann, T.; Braungardt, S. How to make energy efficiency policies in buildings deliver?-The role of refurbishment companies and skilled craft workers. In Proceedings of the International Energy Policy and Programme Evaluation Conference, Vienna, Austria, 26 June 2018.

65. Klinski, S.; Keimeyer, F. Zur Finanzverfassungsrechtlichen Zulässigkeit Eines Nationalen Zertifikatehandels für CO2Emissionen aus Kraft- und Heizstoffen. 2019. Available online: https://www.oeko.de/fileadmin/oekodoc/Verfassungsrecht_ Emissionshandel_Gebaeude-Verkehr.pdf (accessed on 29 September 2021).

66. IKEM; Rodi, M. Verfassungsmäßigkeit des Entwurfs zum Brennstoffemissions-Handelsgesetzes (BEHG-E). Rechtwissenschaftliches Kurzgutachten und Stellungnahme. 2019. Available online: https://www.ikem.de/wp-content/uploads/2019/11/2019-11-05 _IKEM_Kurzgutachten_BEHG-E_final.pdf (accessed on 29 September 2021).

67. Braungardt, S.; Bürger, V.; Hartwig, J. The proposed national emissions trading system in Germany-Discussion of implications for the buildings sector. In Proceedings of the 16th Symposium Energieinnovation, Graz, Austria, 12-14 February 2020.

68. Oeko-Insitut; Fraunhofer ISI; IREES. Treibhausgasminderungswirkung des Klimaschutzprogramms 2030. 2020. Available online: https: / / www.umweltbundesamt.de/publikationen/treibhausgasminderungswirkung-klimaschutzprogramm-2030 (accessed on 29 September 2021).

69. Prognos; Navigant; Oeko-Institut; Ifeu; Adelphi; BBH; Dena. Kurzgutachten zu Maßnahmen zur Zielerreichung 2030 zur Begleitung des Klimakabinetts. 2020. Available online: https://www.bmwi.de/Redaktion/DE/Publikationen/Studien/ kurzgutachten-zu-massnahmen-zur-zielerreichung-2030-zur-begleitung-des-klimakabinetts.pdf?_blob=publicationFile\&v=8 (accessed on 29 September 2021). 